\title{
Phytophthora Species, New Threats to the Plant Health in Korea
}

\author{
Ik-Hwa Hyun ${ }^{1}$ and Woobong Choi ${ }^{2 *}$ \\ ${ }^{I}$ Plant Quarantine Technology Center, Animal and Plant Quarantine Agency, Suwon 443-400, Korea \\ ${ }^{2}$ Department of Biotechnology and Bioengineering, Dongeui University, Busan 614-714, Korea
}

(Received on July 28, 2014; Revised on September 29, 2014; Accepted on October 1, 2014)

Given the lack of a resistant genetic pool in host plants, the introduction of exotic invasive pathogens can result in epidemics that affect a specific ecosystem and economy. Plant quarantine, which is designed to protect endemic plant resources, is a highly invaluable safeguard that should keep biosecurity with increasing international trade and global transportation. A total of 34 species of plant pathogens including Phytophthora infestans were documented as introduced from other countries into Korea from 1900 to 2010 . The genus Phytophthora, classified in oomycetes, includes more than 120 species that are mostly recognized worldwide as highly invasive plant pathogens. After 2000, over 50 new species of Phytophthora were identified internationally as plant pathogens occurring in crops and forest trees. In Korea, Phytophthora is also one of the most serious plant pathogens. To date, 22 species (about onefifth of known species) of the genus have been identified and reported as plant pathogens in the country. The likelihood of new exotic Phytophthora species being introduced into Korea continues to increase, thus necessitating intensive plant quarantine inspections. As new potential threats to plant health in Korea, six Phytophthora species, namely, $P$. alni, $P$. inundata, $P$. kernoviae, $P$. pinifolia, $P$. quercina, and $\boldsymbol{P}$. ramorum, are discussed in this review with focus on history, disease, biology, management, and plant quarantine issues.

Keywords : eradication, exclusion, exotic plant pathogens, plant quarantine, Phytophthora species, P. alni, P. inundata, $P$. kernoviae, $P$. pinifolia, $P$. quercina, $P$. ramorum

*Corresponding author.

Phone) +82-51-890-2279, FAX) +82-51-890-2632

E-mail)wbchoi@deu.ac.kr
Invasive exotic plant pathogens and Phytophthora spp.

An ecosystem is characterized by diverse but balanced biological factors that stem from long-term co-evolution, during which hosts and pathogens interact with each other under various environmental conditions. Plant pathogens infect host plants, which accordingly develop protective mechanisms. Native plant pathogens may not cause dramatic yield loss unless plants are subjected to extreme environmental changes that are conducive to disease development. The introduction of exotic plant pathogens, however, can result in new disease epidemics that can be ecologically and economically difficult to manage. In human history, a number of exotic invasive plant pathogens have considerably influenced the lives of plants and human beings (Agrios, 2011). Phytophthora infestans, which causes late blight in potato, is considered as one of the most destructive exotic plant pathogens; for instance, it was responsible for the Irish potato famine that resulted in the death of more than a million people (Schumann, 1991). $P$. cinnamomi, the causal agent of root rot in a wide range of hosts worldwide, has spread more than 100 years from its presumed center of origin within southeast Asia (Hardham, 2005). The introduction of Cryphonectria parasitica, which causes chestnut blight, resulted in the virtual destruction of American chestnut forests through most of their natural ranges in the US. The damage was inflicted over the course of 30 years. Subsequently, the pathogen was introduced to Europe and affected native chestnut trees in the region (Anagnostakis, 1987).

As indicated by documents, the exotic plant pathogens in Korea have a history of more than 100 years. A total of 34 species were introduced from other countries from 1900 to 2010 (NPQS, 2010). A rapid increase in the identification of newly arriving species occurred after 1970, a year accompanied by the growth of global-scale trade that took place in conjunction with the industrial development of Korea. The risk of invasion by exotic plant pathogens has 
recently become a more serious matter because of the increase in the number of agricultural products imported into the country. Such increase was facilitated by the expansion of the Free Trade Agreement. In addition to new species, new strains are introduced into certain regions, thereby potentially resulting in unexpected damage to plant health. New strains that differ from native or old strains have pathogenic properties or fungicide resistance and can therefore induce newly emerging epidemics. Moreover, genetic exchange between old and new strains may produce "super strains" that possess increased aggressiveness. Under this backdrop, the exclusion and eradication of exotic plant pathogens are major targets stipulated in plant health and quarantine regulations.

The genus Phytophthora, known as the "plant destroyer," is an oomycete previously classified as a fungus but is now considered a fungal-like member of the Kingdom Chromista (Agrios, 2011). The genus currently comprises more than 120 known species (Kroon et al., 2012). After 2000, more than 50 new Phytophthora species were identified worldwide as plant pathogens in crops and forest trees. This rapid increase in the recognition of new Phytophthora species was facilitated by the use of efficient molecular technology and intensive surveys. Many molecular techniques, such as protein electrophoresis, determination of isozyme pattern, PCR-based DNA fingerprinting, and direct sequencing of internal transcribed spacer (ITS) and genes, have been adopted for the effective and rapid identification of the species belonging to Phytophthora. (Kroon et al., 2012).

In Korea, 22 Phytophthora species, including P. cactorum, $P$. capsici, $P$. cinnamomi, $P$. infestans, $P$. nicotianae, P. palmivora, $P$. parasitica, $P$. sojae, and $P$. syringe, have been identified and reported to cause diseases mainly in crop plants (KSPP, 2009). Amid growing concerns over plant health in the country, crop plants have been highlighted as priority types of vegetation for management. A deterrent to this goal is the fact that about $70 \%$ of Korean territory is covered by mountainous areas. The decadeslong and extensive tree planting campaigns spearheaded by the Korean government have resulted in huge biomass- and biodiversity-related changes in the forest ecosystem. Such changes, in turn, have enabled natural resource abundance in forests. Given the increasingly important roles of forest ecosystems in industries and citizen service, more intensive care should be directed toward appropriately maintaining ecosystem health. The case of pine wood nematode is a well-known example of an exotic pest that exerted serious effects on a forest system. This pest particularly affected pine trees and the pine wood industry. After introduction from Japan via contaminated logs, pine wood nematode spread to the southern region of the peninsula and has recently proliferated over the northern part given the climatic change that affects the activity of vector insect, Japanese pine sawyer. The introduction of new Phytophthora species into Korea would threaten plant health both in agricultural and natural forest ecosystems.

This review focuses primarily on Phytophthora species that threaten the health of forest trees. Six Phytophthora species, namely, $P$. alni, $P$. inundata, $P$. kernoviae, $P$. pinifolia, $P$. quercina, and $P$. ramorum, were chosen because of their potential effects. The discussion of these species revolves around history, disease, pathogenic biology, management, and plant quarantine issues.

\section{Phytophthora species that exert potential threats on plant health in Korea}

\section{$P$. alni as causal agent of alder root rot}

History. An unusual Phytophthora species was isolated from dying alder, Alnus glutinous, in southern Britain in 1993 and 1994 (Gibbs, 2003). It killed approximately 10\% of the alders in the region within a few years of its early discovery (Brasier et al., 1995). The pathogen was initially identified as $P$. cambivora, a well-known pathogenic fungus that attacks broadleaved trees but previously unreported for its occurrence in alder. The pathogen was later identified as a new species and formally named Phytophthora alni by Brasier et al. (2004).

Disease. Alder root rot widely grows in Europe, specifically in 18 countries, namely, Austria, Belgium, Czech Republic, England, Estonia, France, Germany, Hungary, Ireland, Italy, Lithuania, The Netherlands, Poland, Scotland, Slovakia, Slovenia, Spain, and Sweden (www.forestry. gov.uk/palni). $P$. alni has recently been found in North America (Adams et al., 2008). In 2007, Oregon listed $P$. alni as one of its "100 most dangerous invasive species." It causes lower stem bark lesions, root and collar necrosis, and crown dieback that are typical of other Phytophthora diseases. Diseased trees do not show crown symptoms until most of the bark at the base of a tree has been killed (Brasier et al., 1995). Typical symptoms in affected trees are abnormally small, yellow, and sparse leaves and the presence of tarry or rusty exudations on stem lesions. P. alni attacks a relatively narrow host range, which includes Alnus cordata, A. glutinosa, A. incana, and A. viridis (Brasier et al., 1995). In greenhouse inoculation trials, Castanea sativa (chestnut), Juglans regia (walnut), and Prunus avium (sweet cherry) were determined as experimental hosts (Santini et al., 
2006). Heavy loss of alders due to Phytophthora infection can cause significant ecological effects, such as changes in forest composition, soil composition, and wildlife food and habitat, as well as increased soil erosion (http://spfnic. fs.fed.us/exfor/data/pestreports.cfm?pestidval=28\&langdisplay $=$ english). Local spread from points of $P$. alni introduction is unlikely related to the movement of oospores because these structures have poor survival ability in soil (Delcan and Brasier, 2001). More likely, zoospores and plant debris that contain mycelium contribute to pathogen movement at this scale. Alders are key trees in wetlands and riparian environments, where they stabilize river and stream banks. In these habitats, the presence of saturated or flooded soils and the occurrence of water movement enhance the spread of zoospores and debris. This scenario is supported by observations of higher disease incidence among alders that grow near rivers than among those growing some distance away (Gibbs et al., 1999).

Biology. The optimum temperature of $P$. alni in culture is $22.5-25.0^{\circ} \mathrm{C}$, with an upper temperature limit at about 30 ${ }^{\circ} \mathrm{C}$ (Brasier et al., 2004). The pathogen is homothallic and produces oospores in culture, but viability is very low and no germination occurs (Brasier et al., 2004). The pathogen has several unusual properties and has been suggested as a new species hybrid, which probably emerged relatively recently (Brasier et al., 1995). Because this new Phytophthora hybrid does not consist of a single entity but comprises a range of phenotypically diverse allopolyploid genotypes, $P$. alni was classified into three subspecies: $P$. alni subsp. alni (Paa), P. alni subsp. multiformis (Pam), and P. alni subsp. uniformis (Pau) (Brasier et al., 2004). Ioos et al. (2006) demonstrated that Paa may have been generated on several occasions by hybridization between Pam and Pau or between their respective ancestors. Pau may have $P$. cambivora as a species ancestor, whereas Pam appears to have grown by itself either via ancient reticulation or via autopolyploidization (Ioos et al., 2006). The variants differ in terms of virulence and pathogenicity toward European alders, but Paa appears to be the most aggressive and pathogenic to such tree species (Brasier and Kirk, 2001). The two other variants, Pam and Pau, appear to be significantly less aggressive than Paa but are still considered pathogenic. The Paa variant is regarded as the primary agent that kills alders in Europe and is the most frequently occurring subspecies in the region.

Plant quarantine issues. Alder trees, including $A$. sibirica, $A$. firma, and $A$. japonica, are important species in Korean forest ecosystems. When $P$. alni is introduced from for- eign countries, the aforementioned alder species may be severely damaged. This pathogen has been regulated as a quarantine pathogen since 2006. Careful inspection should be conducted during quarantine procedures, especially on nursery plants that harbor the pathogen.

\section{$P$. inundata as causal agent of root and collar rot}

History. A new Phytophthora species occurring in horse chestnut was reported in the UK in early 1970, and this Phytophthora was informally designated as belonging to the O-group (Brasier et al., 1993). Brasier et al. (2003) formally identified this pathogen as a new species and named it $P$. inundata, which has also been isolated from a variety of riparian habitats in Europe (Brasier et al., 2003). They occurred in susceptible hosts, such as the ornamental Aesculus and Salix spp., and from commercially cultivated Olea and Prunus spp. after soil flooding or water logging (Brasier et al., 2003). P. inundata was isolated from parsley crops and soil around carrot in Australia (Cunnington et al., 2006), diseased alfalfa roots in the US (Ho et al., 2006), foot and root rot of citrus trees in Chile (Vial et al., 2006), and more recently, from native vegetation in Australia (Stukely et al., 2007). Furthermore, the pathogen was isolated from pistachio trees and infected sugar beet and Solanum dulcamara roots in Iran (Mostowfizadeh-Ghalamfarsa et al., 2006). These results indicate that the worldwide distribution of $P$. inundata is not restricted to trees.

Disease. $P$. inundata causes root and collar rot in ornamental and horticultural shrubs and trees, including Aesculus, Olea, Salix, tobacco, Prunus, and Viburnum. It was also found in alfalfa roots (Parkunan, 2010). Despite these valuable findings, little is known about the disease dispersal and disease cycle of $P$. inundata.

Biology. $P$. inundata is grouped within major ITS clade 6 (Cooke et al., 2000), and its closest relative in the clade is the homothallic P. Humicola, as confirmed in a recent study on Phytophthora species from ITS clade 6 subclade I (Jung et al., 2011). It has nonpapillae sporangia, fairly large oogonia with thick-walled oospores, amphigynous antheridia, and a distinctive colony type. No chlamydospore was observed in many trials (Brasier et al., 2003; Safaiefarahani et al., 2013). P. inundata shows optimal growth at $30^{\circ} \mathrm{C}$ and a high upper temperature limit for growth of $35-37^{\circ} \mathrm{C}$ (Brasier et al., 2003). The pathogen is classically heterothallic, with A1 and A2 compatibility types (Brasier et al., 2003), but it shows many cases of unsuccessful mating, indicating a partial breakdown of the sexual mechanism in the species. Safaiefarahani et al. (2013) reported limited 
variance among isolates from different plants in terms of pathogenicity, molecular attributes, and morphological traits. The authors suggested the possibility of recent derivation of $P$. inundata from other Phytophthora species.

Management. Nested-PCR has been employed as a diagnostic tool for identifying $P$. inundata; this method is also a reliable and effective way of detecting infection in host plant parts and infested soil (Safaiefarahani et al., 2013). Appropriate water management is highly recommended in the cultivation of known hosts with $P$. inundata infection. The practical application of fungicide treatment methods, such as the use of phosphonates, requires further investigation.

Plant quarantine issues. $P$. inundata has not been listed as a quarantine pathogen in Korea. A pest risk assessment is required for $P$. inundata to be included in the list and for the species to be further examined.

$P$. kernoviae as causal agent of trunk canker, leaf blight, and stem dieback

History. An unknown Phytophthora species was discovered from a bleeding lesion on a mature European beech, Fagus sylvatica, and concurrently from Rhododendron in 2003 in the southwest of England during surveys on $P$. ramorum. The new Phytophthora was informally designated Phytophthora taxon $\mathrm{C}$ and later named $P$. kernoviae by Brasier et al. (2005). Since then, P. kernoviae has also been found in Scotland, Ireland, and New Zealand (EPPO, 2013).

Disease. Two different symptoms are observed: bleeding cankers and leaf lesions (Brasier et al., 2005). Identifying the symptoms caused by $P$. kernoviae can be a confusing task because such symptoms are similar to those caused by $P$. ramorum. $P$. kernoviae sporulates on foliage hosts and is dispersed by rain to bole hosts where cankers develop. The pathogen attacks Aesculus hippocastanum, Annona cherimola, Castanea sativa, Drimys winteri, Fagus sylvatica (European beech), Gevuina avellana (Chilean hazelnut), Hedera helix, Ilex aquifolium, Liriodendron tulipifera (tulip tree), Lomatia myricoides, Magnolia sp., Michelia doltsopa, Pieris spp., Podocarpus salignus, Prunus laurocerasus, Quercus ilex (holm oak), Q. robur (English oak), Rhododendron ponticum, Sequoiadendron giganteum, and Vaccinium myrtillus (EPPO, 2013). On the basis of experience with $P$. ramorum, the host range of $P$. kernoviae is expected to expand with time and more surveys. A regularly updated host list can be found on the Defra website (http:// www.gov.uk/defra). Caduceus sporangia with zoospores most probably spread locally by water splash or through airborne mist droplets. Under suitable conditions, asexual reproduction takes place and new sporangia are produced. Oospores have been produced by $P$. kernoviae under laboratory conditions but have not been observed in naturally infected plants. Chlamydospores have never been observed in the laboratory or in the field (EPPO, 2013). Further studies on the disease cycle of $P$. kernoviae are needed. Longdistance spreading can be facilitated by the movement of infected rhododendron, beech, and other hosts. P. kernoviae is apparently not a root pathogen, but it can be isolated from soil. Soil movement may also spread the disease. $P$. kernoviae appears to be more virulent than $P$. ramorum on some hosts. The potential risk of lateral transfer of genes from other Phytophthora should be examined further. Similar to $P$. ramorum, $P$. kernoviae presents a risk to both forestry and nursery industries (EPPO, 2013).

Biology. The optimal temperature for $P$. kernoviae growth on carrot agar is approximately $18^{\circ} \mathrm{C}$, with the upper growth temperature limit at around $26^{\circ} \mathrm{C}$ (Brasier et al., 2005). This temperature maximum is slightly higher than those of $P$. hibernalis, $P$. illicis, and $P$. nemorosa but significantly lower than those of $P$. botryosa, $P$. heveae, $P$. katsurae, P. meadii, and P. megakarya (Gallegly and Hong, 2008). These temperature differences can be used as an additional characteristic that distinguishes $P$. kernoviae from other species with a similar morphology. The growth characteristics on agar and morphological features of $P$. kernoviae are described in Brasier et al. (2005). The pathogen is homothallic and produces amphigynous antheridia and caducous and conspicuously papillate sporangia (Brasier et al., 2005). Although oospore production is abundant in culture, the pathogen's ability to produce oospores in naturally infected plant tissues remains unknown (Brasier et al., 2005). Because chlamydospores have not been reported for this species, oospore production and subsequent survival can serve as critical epidemiological factors. The origin of $P$. kernoviae is currently unknown.

Management. P. kernoviae can be detected in host tissue by direct isolation, ELISA, and real-time TaqMan PCR (EPPO, 2013). However, because P. kernoviae has also been associated with asymptomatic tissues, monitoring poses special challenges for inspectors and regulators. Such challenges are attributed to the possibility that roots and asymptomatic tissues may be hidden pathways of movement. Two real-time TaqMan diagnostic procedures for the detection of $P$. kernoviae have been reported in the literature: 
one relies on the ITS region in detection and the other uses the spacer region in the ras-related protein Ypt 1 (Schena et al., 2006). Thus far, control measures are essentially based on the destruction of infected plants, particularly rhododendrons in infected woodlands. More studies on possible practical control measures are required.

Plant quarantine issues. The introduction of $P$. kernoviae to Korea can threaten both forest and nursery systems. A necessary task is to create a $P$. kernoviae risk map that considers climate, host density, sporulation potential, and introduction pathways. A monitoring program is also required to determine whether P. kernoviae has occurred or has been introduced to Korea.

\section{$P$. pinifolia as causal agent of pine needle blight}

History. Since 2004, a new disease that affects Pinus radiata has occurred in the Arauco province of Chile and subsequently spread to other areas. Referred to as "Daño Foliar del Pino" (DFP), the disease was officially named the pathogen $P$. pinifolia by Duran et al. (2008).

Disease. $P$. pinifolia is presently known to occur only in Chile, and the pathogen causes serious needle blight. Symptoms begin with a reddening of the past year's needles in early winter. The first needles to display symptoms are those on the lower sides of branches. Needles die and assume a distinctly gray color and begin to fall. Initially, dead and dying needles are retained on branches, thereby giving trees the appearance of having been severely scorched. The needles then fall from the trees, which can be almost completely defoliated. New needle growth is unaffected and trees appear to recover until infection re-occurs in the following season. After two or three years of defoliation, trees occasionally die; death may be hastened by infection from Diplodia pinea (Diplodia blight of pine), which is a well-known opportunistic pathogen (Duran et al., 2008). Pinus radiata (Monterey pine) is the only known natural host for $P$. pinifolia, but Ahumada et al. (2013) found that $P$. pinifolia is not specific to $P$. radiata and infects many other tested Pinus species. In Korea, P. densiflora, P. koraiensis, and $P$. thunbergii are the major species in pine tree forests. These Korean pine tree species were not included in the pathogenicity test conducted by Ahumada et al. (2013). DFP is generally recognized in Chile as the most serious problem to have affected pine forestry in the country (Duran et al., 2008). The discovery of an aerial Phytophthora spp., which causes serious disease in Chilean $P$. radiata, adds to the new and serious tree-infecting aerial Phytophthora spp. that have recently been discovered. Newly planted seed- lings and naturally regenerated plants die when infected in the first year of growth. Such death rate makes $P$. pinifolia a serious threat to reforestation.

Biology. Although the symptoms of DFP in Chile are consistent with the biology of an aerial $P$. pinifolia, many as-yet unanswered questions surround the biology of the pathogen. Sporangia are assumed to be the infective propagules, but such proposition requires experimental support. Sporangia proliferate to a limited extent in culture; thus, natural conditions in which to produce them should be developed. Infection studies that use zoospores are needed, and the infection biology and lifecycle of the pathogen remain unelucidated (Duran et al., 2008). Ahumada et al. (2013) reported that sporangia commonly remain on needles for extended periods under rainy conditions.

Plant quarantine issues. The National Plant Quarantine Service has prohibited the import of $P$. radiata seeds, seedlings, hard wood, and lumber from Chile since 2008.

\section{$P$. quercina as causal agent of oak decline}

History. P. quercina causes oak decline and root rot in oak. $P$. quercina was initially observed in central and southern Europe in early 1990 and formally named by Jung et al. (1999). The species name "quercina" was taken from the Latin word for oak, quercus.

Disease. Oak decline by $P$. quercina was later identified in European countries, including Austria, Belgium, France, Germany, Hungary, Italy, Luxemburg, Serbia and Montenegro, Sweden, Turkey, and the UK (Balcì and Halmschlager, 2002, 2003; Cooke et al., 2005; Jönsson et al., 2003,). Above-ground symptoms include dieback in branches and parts of the crown, formation of epicormic shoots, high transparency of the crown, yellowing and wilting of leaves, and tarry exudates from the bark (Siwecki and Liese, 1991). Host plants are oak species, such as Quercus cerris, Q. frainetto, $Q$. hartwissiana, $Q$. ilex, $Q$. petraea, $Q$. pubescens, $Q$. robur, and $Q$. vulcanica. Little is known about disease development.

Biology. In culture, $P$. quercina shows a uniform, domeshaped, and cottonwool-like pattern of colony growth. The optimum growth temperature is close to $25^{\circ} \mathrm{C}$ and no growth occurs at $30^{\circ} \mathrm{C}$. P. quercina frequently presents sympodially branched primary hyphae. Sporangia considerably vary in size and shape, and spherical chlamydospores are occasionally produced. P. quercina is homothallic and shows a high proportion of elongated, ellipsoid, or 
ovoid oogonia and the absence of amphigynous antheridia. Oospores are spherical to ovoid, and older oospore walls often turn golden-yellow (Cooke et al., 2005; Jung et al., 1999).

Management. The identification of isolates is based on cultural and morphological features and on comparisons with authentic cultures. The sequences (two isolates) and restriction digest patterns (nine isolates) of the internal transcribed spacer (ITS) regions of rDNA from Austrian $P$. quercina are identical. The digest patterns match those of Italian, Hungarian, and German strains (Cooke et al., 1999), including the aggressive strains used by Jung et al. (1999) for inoculation tests, although pathogenicity tests were not carried out on Austrian isolates.

Plant quarantine issues. Oak trees are important amenity and forest components in Korea, and P. quercina has been included since 2004 in the quarantine pathogen list for the inspection of imported plant material.

Phytophthora ramorum: The pathogen that causes sudden oak death

History. Unknown symptoms of foliar blight and twig dieback in rhododendron plants in a nursery were first recognized in the Netherlands in 1993, then in Germany in 1995 in the same host species (Werres et al., 2001). During the same period, an unusually lethal symptom was observed in the tanoaks of forests in Mill Valley, Marin County, California (Svihra, 2001). P. ramorum was identified as the causal agent of this phenomenon and is currently known to cause sudden oak death (SOD) in the forests located in the Pacific side of North America and ramorum blight or dieback in woody ornamental plants in Europe (Rizzo et al., 2002; Werres et al., 2001). The pathogen has also recently been reported to cause sudden larch death in the UK (Brasier and Webber, 2010).

Disease. In Canada, $P$. ramorum was detected in nurseries in British Columbia from 2004 to 2007; traces of the pathogen in all locations were eradicated (Official site: Canadian Food Inspection Agency). In Europe, P. ramorum has been observed in more than 23 countries, including Belgium, Czech Republic, Denmark, Estonia, Finland, France, Germany, Ireland, Italy, Latvia, Lithuania, Luxembourg, the Netherlands, Poland, Portugal, Slovenia, Spain, Sweden, the UK, Norway, Switzerland, Greece, and Croatia (Redlin et al., 2014). In California, since the first observation of pathogen occurrence in 1995, $P$. ramorum has proliferated in the forest systems of California, Oregon, and Washing- ton along a 1,500 km stretch of forests located in the Pacific side of the region, as well as in the nursery systems of 23 states. No disease occurrence induced by P. ramorum has been reported for Africa, Asia, Australia, and South America. In contrast to other Phytophthora species, P. ramoruminfected plants show symptoms on the upper part of the plants and not on the root. The name "ramorum" means "branch" in Latin. Three main symptoms are observed on infected plants: leaf blight, twig blight (dieback), and stem canker. Leaf blight and twig blight are symptoms of ramorum blight disease in ornamental woody plants. Stem canker is a typical symptom of SOD, which was first referred to in the media as a phenomenon that occurs in oak forests. Ramorum leaf blight and ramorum dieback are considered acceptable academic disease names (Henricot and Prior, 2004). Nonlethal foliar infection in woody shrubs or other hosts in understories serve as a source of inoculum for trees (Davidson et al., 2005). P. ramorum invades susceptible trees through the bark, on which cankers with tarry or rusty exudations develop. The leaves of infected trees may later take on a brown color over a short period and the trees eventually die (Garbelotto et al., 2001). The host range of $P$. ramorum has expanded, and official websites in Canada, the EU, and the US display the updated host list. The number of host plants currently amounts to about 120-130 species.

$P$. ramorum spreads in forests through rain and wind, river and streams, and human activities (Grunwald et al., 2012). The role of a vector in $P$. ramorum disease was discussed by McPherson (McPherson et al., 2013). The effects of $P$. ramorum differ depending on ecosystem and host. In natural (forest) and semi-natural (plantation) ecosystems, extensive mortality of trees and shrubs can exert severe ecological consequences, including significant changes in the structure and composition of plant and animal communities and increased water runoff and associated soil erosion. P. ramorum exerts significant economic effects on forests because it reduces recreational, cultural, or commodity value and increases the costs of monitoring and eradication measures.

Biology. P. ramorum was identified by Werres et al. (2001) as a pathogen that causes leaf and twig blight in woody ornamental plants, including the rhododendron and Viburnum species in Europe. Rizzo et al. (2002) confirmed that $P$. ramorum is also the pathogen that causes SOD in the forests located in the Pacific region of the US. "Ramorum" refers to the disease symptoms that manifest on branches because this Latin word means "branch." Within the genuswide phylogeny, $P$. ramorum is classified in Phytophthora 
Clade $8 \mathrm{c}$, and its closest relatives include $P$. foliorum, $P$. hibernalis, and $P$. lateralis (Blair et al., 2008). P. ramorum is characterized by the production of sporangia and abundant large chlamydospores. The sporangia of $P$. ramorum are elongated, deciduous, semi-papillate, and similar to those of P. palmivora (Werres et al., 2001). Motile zoospores are released from sporangia; upon contact with susceptible host tissue, the zoospores encyst, germinate, and penetrate the host tissue (Davidson et al., 2005). Chlamydospores are abundantly produced within infected plant tissue and enable $P$. ramorum to survive adverse conditions in infected plant stems and leaves, plant debris on the soil surface, or soil (Tooley et al., 2008). The concept of clonal lineage has been applied in the intraspecies classification of $P$. ramorum. Originally, Ivors et al. (2006) proposed three clonal lineages, namely, EU1, NA1, and NA2, which were standardized by Grunwald et al. (2009). EU2 was later added by Poucke et al. (2012) as the fourth clonal lineage when an epidemic of sudden larch death occurred in the UK. Clonal lineages are distinguished by molecular marker systems, including AFLP, SSR genotypes, and DNA sequences. Table 1 lists the four clonal lineages and their important properties in terms of geographical distribution, habitat, growth, aggressiveness, and mating type. The geographical distribution of four known clonal lineages of $P$. ramorum is restricted to two continents, Europe and North America. EU1 presents in Europe in major clonal lineages and in the US as a minor lineage in the nurseries of Oregon and Washington. EU2 has recently been observed in the UK. NA1 is a major clonal lineage in California and NA2 occurs only in British Columbia, Canada, and Washington. Along with geographical distribution, habitat is an important factor in understanding the lifecycle of the pathogen for the purpose of managing the disease. EU1 was isolated from forests, nurseries, and gardens in Europe but only in nurseries in North America. EU2 was identified in forests and nurseries, with limited cases in the UK (Poucke et al., 2012). NA1 is a major lineage in California, Oregon, and Washington forests and is currently spreading to the east side of the US through the nursery industry. NA2 is rarely observed in California and more commonly occurring in the nursery habitats of British Columbia, Canada, and Washington. Significant differences exist among lineages in terms of important fitness characteristics, such as growth rate and aggressiveness. EU1 and NA2 grow faster and more aggressively than does NA1 (Brasier et al., 2006; Brasier, 2003; Manter et al., 2010). However, NA1 is a major clonal lineage that causes SOD in the US. P. ramorum is heterothallic and exhibits different mating types for sexual reproduction. EU1 and EU2 are of mating type A1. Findings show that EU1 exhibited mating type A2 in Belgium around 2002-2003 (Werres and De Merlier, 2003). After eradication, no further occurrences of A2 mating type were observed in Europe (Vercauteren et al., 2011). NA1 and NA2 are both of mating type A2. The assessment of the risk posed by the sexual reproduction of $P$. ramorum in natural environments is complicated. The current likelihood for sexual recombination in Europe is therefore limited. By contrast, A1 (EU1) and A2 (NA1 and NA2) isolates have simultaneously occurred in the US (Grunwald et al., 2008; Hansen et al., 2003), suggesting a higher chance of sexual reproduction in the region. The main risk generated by sexual reproduction is the appearance of a "Red Queen," a progeny with particular fitness and high aggressiveness that can circumvent plant resistance mechanisms, as was demonstrated for the US-11 lineage of $P$. infestans (Gavino et al., 2000). In the case of $P$. ramorum, the colonization of a new environment and new hosts are the main threat. The origins of the clonal lineages, except for EU1, are unknown; EU1 originated from North America, after which it dispersed from Europe to British Columbia and Washington (Grunwald et al., 2012). Then, it migrated to California and Oregon. Reasonable evidence shows that NA1 originated from nurseries in Scotts Valley, California and NA2 originated from British Columbia or Washington (Grunwald et al., 2012). The nursery industry is an important pathway for the global migration of $P$. ramorum.

Management. The recognition of $P$. ramorum via symptoms is difficult because the manifestations induced by $P$. ramorum are variable and often rarely distinguishable from those produced by other pathogens, including other

Table 1. Four clonal lineages in P. ramorum

\begin{tabular}{ccccc}
\hline $\begin{array}{c}\text { Clonal } \\
\text { lineage }\end{array}$ & $\begin{array}{c}\text { Geographical } \\
\text { distribution }\end{array}$ & Habitat & $\begin{array}{c}\text { Growth/ } \\
\text { Pathogenicity }\end{array}$ & Mating type \\
\hline EU1 & Europe, US & nursery & faster/higher & A1 \\
\hline EU2 & Europe & forest, nursery & $-/-$ & A1 \\
\hline NA1 & North America (Pacific side) & forest, nursery, graden & slower/lower & A2 \\
\hline NA2 & North America (British Columbia, Washington) & nursery & faster/higher & A2 \\
\hline
\end{tabular}


Phytophthora species. Culturing on selective media and by molecular methods have been adopted in diagnosing $P$. ramorum infection. Although culturing diagnosis is generally ineffective, this method has been used under stress environments to discriminate a certain clonal lineage from others in terms of phenotypic assessment (Franceschini et al., 2014). The method effectively differentiates EU2 from other clonal lineages with relatively simple culturing tests. Otherwise, DNA-based molecular methods, including PCR and fingerprinting, are commonly used techniques in detecting $P$. ramorum (Bilodeau et al., 2007; Tomlinson et al., 2010). Chemical treatments, such as fungicides and disinfectants, are important components of integrated pest management practices aimed at controlling and limiting the spread of $P$. ramorum. Numerous studies have examined the use of fungicides to control $P$. ramorum in ornamentals (Garbelotto et al., 2009; Perez-Sierra et al., 2011). Asymptomatic plant material is the main route of Phytophthora spp. introduction to nurseries. Fungicides produce asymptomatic plant material, which is the main route for the internursery spread of $P$. ramorum. Although fungicides are somewhat effective preventive treatments, repeated applications potentially lead to fungicide resistance by the pathogen, as has been observed in other Phytophthora spp. In addition, US and European Union regulations prohibit the application of fungicides in quarantine zones because of potential masking of the symptoms mentioned above.
Biological control is an alternative option for managing $P$. ramorum disease. Several studies have assessed the potential of biological organisms to control P. ramorum. Researchers have recently identified three isolates, namely, Penicillium daleae, P. herquei, and Metarhizium anisopliae, which showed that fungi applied to the leaf surface can reduce the necrosis caused by $P$. ramorum (Widmer and Dodge, 2013). Whether resistance to P. ramorum is possible requires further examination. Nettel et al. (2011) indicated that tanoaks are susceptible to the pathogen and that no evidence of prior selection for disease resistance exists. The authors concluded that tanoak populations across the species' range are at risk.

Plant quarantine issues. Pathogen occurrence in Korea has not been reported, but Korean officials formulated a disease name that matches SOD because oak trees are valuable components in the forest ecosystems of Korea. In these systems, more than 10 species of oaks, including Quercus species, grow with complex characteristics. Oak trees are important for their roles in the ecosystem. They contribute to land greening, thumb, provide food supply for wildlife and habitats for birds and other animals, serve as material in the mushroom growing industry, and are used for recreation purposes. In Korea, oak trees have suffered from a number of diseases, including leaf spot disease, powdery mildew, stem-end branch rot, root rot, and canker

Table 2. Six Phytophthora species threatening forest tree species in Korea

\begin{tabular}{|c|c|c|c|c|c|c|}
\hline Species & Disease & $\begin{array}{c}\text { Year } \\
\text { first identified }\end{array}$ & Host range & Distribution & $\begin{array}{c}\text { Sexual } \\
\text { Reproduction }\end{array}$ & $\begin{array}{c}\text { Year for quarantine } \\
\text { regulation } \\
\text { in Korea }\end{array}$ \\
\hline P. alni & Alder root rot & $1993 \sim 1994$ & $\begin{array}{l}\text { Alder } \\
\text { Chestnut } \\
\text { Walnut } \\
\text { Cherry }\end{array}$ & $\begin{array}{c}\text { Europe } \\
\text { North America }\end{array}$ & Homothallic & 2006 \\
\hline P. inundata & $\begin{array}{l}\text { Root rot } \\
\text { Collar rot }\end{array}$ & 1970 & $\begin{array}{l}\text { Aescules } \\
\text { Salix } \\
\text { Chestnut }\end{array}$ & Worldwide & Heterothallic & Not listed yet \\
\hline P. kernoviae & canker & 2003 & $\begin{array}{l}\text { Similar to } P \text {. ramorum } \\
\text { Expanding annually }\end{array}$ & $\begin{array}{c}\text { England } \\
\text { Ireland } \\
\text { New Zealand }\end{array}$ & Homothallic & 2006 \\
\hline P. pinifolia & Pine needle blight & 2004 & Pine & Chile & Not Examined & 2008 \\
\hline P. quercina & Root rot & 1993 & Oaks & $\begin{array}{c}\text { Europe } \\
\text { Asia } \\
\text { USA }\end{array}$ & Homothallic & 2004 \\
\hline P. ramorum & $\begin{array}{l}\text { Stem canker (SOD) } \\
\text { Blight of leaf or twig }\end{array}$ & Early 1990’ & $\begin{array}{l}\text { Oak trees and } \\
\text { woody plants }\end{array}$ & $\begin{array}{c}\text { Europe, } \\
\text { North America }\end{array}$ & Heterothallic & 2004 \\
\hline
\end{tabular}


(KSPP, 2009). Given that the host range of $P$. ramorum is extremely wide and continues to spread to expansive regions, its effects on the forest ecosystems in Korea would be critical when the pathogen is introduced into the country. The quarantine of $P$. ramorum has caused significant economic hardship to the nursery industry in Europe and North America. Internationally, regulations that prohibit the import of potentially infested material were issued by Australia, Canada, the Czech Republic, the UE, Mexico, New Zealand, South Korea, Taiwan, and the UK. In 2009, more than 68 countries, including China, either included $P$. ramorum on their lists of regulated pests or mentioned the pathogen in their legislation (Sansford et al., 2009). Evidence as to the areas where $P$. ramorum are endemic may be derived from an examination of the distribution of its closest known relatives in Phytophthora Clade 8c, $P$. lateralis, $P$. hibernalis, and $P$. foliorum. Following its recent discovery in Taiwan, $P$. lateralis is now considered native to Taiwan, and possibly, Japan (Brasier et al., 2010). By analogy, P. ramorum has therefore been suggested as originating from Taiwan and Japan and perhaps Yunnan, China. Thus far, however, surveys on P. ramorum in Taiwan and Yunnan have generated negative results.

\section{Conclusion}

Table 2 shows the six Phytophthora species reviewed in this article. New Phytophthora species have been rapidly identified as plant pathogens after 1990 through largescale surveys and more efficient detection and identification technologies. These new Phytophthora pathogens are geographically distributed with a widening host range and increasing effects on agriculture, environments, and related industries. In particular, the Phytophthora discussed in this review can cause huge losses in the Korean forest ecosystems and ornamental industry when introduced to the country. Pine (46\%) and oak (18\%) with associated alder trees are major components of the forest ecosystems in Korea, and Prunus is an important fruit tree in the country (KFPI, 2013). Managing the diseases that affect forest trees is difficult because of the lack of effective control methods and the challenges posed by treatment. The rapid increase in international transportation, tours, and global climatic change would elevate the chances that new invasive pathogens will be introduced from one region to another. The introduction of exotic plant pathogens can cause new disease epidemics that can be difficult to manage because of the lack of genetic resources for resistance. Such sources are produced by co-evolution between hosts and pathogens. Pine wilt nematode, which is not problematic in the US from where it originated, has reached uncontrollable proportions in Japan and Korea, where nematode was newly introduced. The introduction of new plant pathogens affects not only the yield of target host plants, but also product industries and international trade. The importance of plant quarantine cannot be overemphasized because of effects of newly introduced invasive pests and pathogens. The Phytophthora species discussed in this review are included in the Korean Plant Pathogen Quarantine list, with the exception of $P$. inundata, which should be listed after pest risk assessment. Once listed, intensive inspection will be performed for imported plants and products. To this end, rapid and efficient detection methods should be developed and applied. Effective protocols should also be implemented in managing newly introduced pathogens.

\section{Acknowledgment}

This research was supported by Dongeui University Research Grant 2014AA216.

\section{References}

Agrios, G. N. 2011. Plant pathology, 6th ed. Academic Press, San Diego, 922pp.

Ahumada, R., Rotella, A., Slippers, B. and Wingfield, B. D. 2013. Pathogenicity and sporulation of Phytophthora pinifolia on Pinus radiata in Chile. Australas. Plant Pathol. 42:413-420.

Anagnostakis, S. L. 1987. Chestnut blight: the classical problem of an introduced pathogen. Mycologia 79:23-27.

Bakonyi, J., Nagy, Z. Á. and Érsek, T. 2007. A novel hybrid with nuclear background of Phytophthora alni subsp. alni exhibits a mitochondrial DNA profile characteristic of $P$. alni subsp. uniformis. Acta Phytopathol. Entomol. Hung. 42:1-7.

Balcì, Y. and Halmschlager, E. 2003. First report of Phytophthora quercina from oak forests in Austria. Plant Pathol. 52:403.

Bilodeau, G. J., Lévesque, C. A., de Cock, A. W. A. M., Duchaine, C., Brière, S., Uribe, P., Martin, F. N. and Hamelin, R. C. 2007. Molecular detection of Phytophthora ramorum by realtime polymerase chain reaction using TaqMan, SYBR Green, and molecular beacons. Phytopathology 97:632-642.

Blair, J. E., Coffey, M. D., Park, S. Y., Geiser, D. M. and Kang, S. 2008. A multi-locus phylogeny for Phytophthora utilizing markers derived from complete genome sequences. Fungal Genet. Biol. 45:266-277.

Brasier, C. M., Beales, P. A., Kirk, S. A., Denman, S. and Rose, J. 2005. Phytophthora kernoviae sp. nov., an invasive pathogen causing bleeding stem lesions on forest trees and foliar necrosis of ornamentals in Britain. Mycol. Res. 109:853-859.

Brasier, C. M. and Kirk, S. A. 2001. Comparative aggressiveness of standard and variant hybrid alder Phytophthoras, Phytophthora cambivora and other Phytophthora species on the bark of Alnus, Quercus and other woody hosts. Plant Pathol. 
50:218-229.

Brasier, C. M. and Kirk, S. A. 2004. Production of gametangia by Phytophthora ramorum in vitro. Mycol. Res. 108:823-827.

Brasier, C. M., Kirk, S. A., Delcan, J., Cooke, D. E., Jung, T. and Man in't Veld, W. A. 2004. Phytophthora alni sp. nov. and its variants: designation of emerging heteroploid hybrid pathogens spreading on Alnus trees. Mycol. Res. 108:1172-1184.

Brasier, C. M., Rose, J. and Gibbs, J. N. 1995. An unusual Phytophthora associated with alder mortality in Britain. Plant Pathol. 44:999-1007.

Brasier, C. M., Sánchez-Hernández, E. and Kirk, S. A. 2003. Phytophthora inundata sp. nov., a part heterothallic pathogen of trees and shrubs in wet or flooded soils. Mycol. Res. 107:477484.

Brasier, C. M., Vettraino, A. M., Chang, T. T. and Vannini, A. 2010. Phytophthora lateralis discovered in an old growth Chamaecyparis forest in Taiwan. Plant Pathol. 59:595-603.

Brasier, C. and Webber, J. 2010. Plant pathology: sudden larch death. Nature 466:824-825.

Cooke, D. E. L., Drenth, A., Duncan, I. M., Wagels, G. and Brasier, C. M. 2000. A molecular phylogeny of Phytophthora and related Oomycetes. Fungal Genet. Biol. 30:17-32.

Cooke, D. E. L., Jung, T., Williams, N. A., Schubert, R., Bahnweg, G., Osswald, W. and Duncan, J. M. 1999. Molecular evidence supports Phytophthora quercina as a distinct species. Mycol. Res. 103:799-804.

Cooke, D. E. L., Jung, T., Williams, N. A., Schubert, R., Osswald, W. and Duncan, J. M. 2005. Genetic diversity of European populations of the oak fine-root pathogen Phytophthora quercina. For. Pathol. 35:57-70.

Cunnington, J. H., Jones, R. H., de Alwis, S. and Minchinton, E. J. 2006. Two new Phytophthora records for Australia. Australas. Plant Pathol. 35:383-384.

Davidson, J. M., Wickland, A. C., Patterson, H. A., Falk, K. R. and Rizzo D. M. 2005. Transmission of Phytophthora ramorum in mixed-evergreen forest in California. Phytopathology 95:587-596.

Delcan, J. and Brasier, C. M. 2001. Oospore viability and variation in zoospore and hyphal tip derivates of the hybrid alder Phytophthoras. For. Pathol. 31:65-83.

Durán, A., Gryzenhout, M., Slippers, B., Ahumada, R., Rotella, A., Flores, F., Wingfield, B. D. and Wingfield, M. J. 2008. Phytophthora pinifolia sp. nov., associated with a serious needle disease of Pinus radiata in Chile. Plant Pathol. 57:715-727.

European and Mediterranean Plant Protection Organization. 2013. PM 7/112 (1) Phytophthora kernoviae. EPPO Bulletin 43:81-93.

Franceschini, S., Webber, J. F., Sancisi-Frey, S. and Brasier, C. M. 2014. Gene $\times$ Environment Tests discriminate the new EU2 evolutionary lineage of Phytophthora ramorum and indicate that it is adaptively different. For. Pathol. 44:219-232.

Gallegly, M. E. and Hong, C. 2008. Phytophthora: Identifying species by morphology and DNA fingerprints. The American Phytopathological Society. APS Press, 518pp
Garbelotto, M. and Schmidt, D. J. 2009. Phosphonate controls sudden oak death pathogen for up to 2 years. Calif. Agric. 63:10-17.

Garbelotto, M., Svihra, P. and Rizzo, D. M. 2001. Sudden oak death syndrome fells 3 oak species. Calif. Agric. 55:9-19.

Gavino, P. D., Smart, C. D., Sandrock, R. W., Miller, J. S., Hamm, P. B., Lee, T. Y., Davis, R. M. and Fry, W. E. 2000. Implications of sexual reproduction for Phytophthora infestans in the United States: Generation of an aggressive lineage. Plant Dis. 84:731-735.

Gibbs J. N., Lipscombe M. A. and Peace, A. J. 1999. The impact of Phytophthora disease on riparian populations of common alder (Alnus glutinosa) in southern Britain. Eur. J. Forest Pathol. 29:39-50.

Gibbs, J. N., van Dyck, C. and Webber, J. F. 2003. Phytopthora disease of alder. For. Comm. Bull. 126:1-82.

Grunwald, N. J., Garbelotto, M., Goss, E. M., Heungens, K. and Prospero, S. 2012. Emergence of the sudden oak death pathogen Phytophthora ramorum. Trends Microbiol. 20:131-138.

Grunwald, N. J., Goss, E. M., Ivors, K., Garbelotto, M., Martin, F. N., Prospero, S., Hansen, E., Bonants, P. J. M., Hamelin, R. C., Chastagner, G., Werres, S., Rizzo, D. M., Abad, G., Beales, P., Bilodeau, G. J., Blomquist, C. L., Brasier, C., Briere, S. C., Chandelier, A., Davidson, J. M., Denman, S., Elliott, M., Frankel, S. J., Goheen, E. M., de Gruyter, H., Heungens, K., James, D., Kanaskie, A., McWilliams, M. G., in't Veld, W. M., Moralejo, E., Osterbauer, N. K., Palm, M. E., Parke, J. L., Sierra, A. M. P., Shamoun, S. F., Shishkoff, N., Tooley, P. W., Vettraino, A. M., Webber, J. and Widmer, T. L. 2009. Standardizing the nomenclature for clonal lineages of the sudden oak death pathogen, Phytophthora ramorum. Phytopathology 99:792-795.

Grunwald, N. J., Goss, E. M. and Press, C. M. 2008. Phytophthora ramorum: a pathogen with a remarkably wide hostrange causing sudden oak death on oaks and ramorum blight on woody ornamentals. Mol. Plant Pathol. 9:729-740.

Hansen, E. M., Reeser, P. W., Sutton, W., Winton, L. M. and Osterbauer, N. 2003. First report of A1 compatibility type of Phytophthora ramorum in North America. Plant Dis. 87:1267.

Hardham, A. R. 2005. Phytophthora cinnamomi. Mol. Plant Pathol. 6:589-604.

Henricot, B. and Prior, C. 2004. Phytophthora ramorum, the cause of sudden oak death or ramorum leaf blight and dieback. Mycologist 18:151-156.

Ho, H. H., Hong, C. X. and Erwin, D. C. 2006. Phytophthora inundata isolated from diseased alfalfa roots in Southern California. Mycotaxon 97:349-358.

Ioos, R., Andrieux, A., Marçais, B. and Frey, P. 2006. Genetic characterization of the natural hybrid species Phytophthora alni as inferred from nuclear and mitochondrial DNA analyses. Fungal Genet. Biol. 43:511-529.

Ivors, K., Garbelotto, M., Vries, I. D., Ruyter-Spira, C., Te Hekkert, B., Rosenzweiq, N. and Bonants, P. 2006. Microsatellite 
markers identify three lineages of Phytophthora ramorum in US nurseries, yet single lineages in US forest and European nursery populations. Mol. Ecol. 15:1493-1505.

Jönsson, U., Lundberg, L., Sonesson, K. and Jung, T. 2003. First record of soilborne Phytophthora species in Swedish oak forests. For. Pathol. 33:175-179.

Jung, T., Cooke, D. E. L., Blaschke, H., Duncan, J. M. and Osswald, W. 1999. Phytophthora quercina sp. nov., causing root rot of European oaks. Mycol. Res. 103:785-798.

Jung, T., Stukely, M. J. C., Hardy, G. E. S. J., White, D., Paap, T., Dunstan, W. A. and Burgess, T. I. 2011. Multiple new Phytophthora species from ITS Clade 6 associated with natural ecosystems in Australia; evolutionary and ecological implications. Persoonia 26:13-39.

Korea Forestry Promotion Institute (KFPI). 2013. Assessment of the Korea's forest resources (2006-2012). KFPI, Anyang, Korea, 267pp. (in Korean)

Kroon, L. P. N. M., Brouwer, H., de Cock, A. W. A. M. and Govers, F. 2012. The Genus Phytophthora Anno 2012. Phytopathology 102:348-364.

McPherson, B. A., Erbilgin, N., Bonello, P. and Wood, D. L. 2013. Fungal species assemblages associated with Phytophthora ramorum-infected coast live oaks following bark and ambrosia beetle colonization in northern California. Forest Ecol. Manag. 291:30-42.

Mostowfidadeh-Ghalamfarsa, R., Cooke, D. E. and Banihashemi, Z. 2006. Multiple gene genealogies approach for phylogenetic relationship of Phytophthora inundata and other Phytophthoras. In: Proceedings of 17th Iranian Plant Protection Congress, September 2006, Karaj, Iran, 434 (abstract).

National Plant Quarantine Service (NPQS) 2010. Compendium of exotic plant pests and weeds. NPQS, Anyang, Korea, 292pp. (in Korean)

Nettel, A., Hayden, K. J., Garbelotto, M. and Dodd, R. S. 2011. Will all the trees fall? Variable resistance to an introduced forest disease in a highly susceptible host. For. Ecol. Manage. 261:1781-1791.

Parkunan, V., Johnson, C. S., Bowman, B. C. and Hong, C. X. 2010. First report of Phytophthora inundata associated with a latent infection of tobacco (Nicotiana tabacum) in Virginia. Plant Pathol. 59:1164.

Perez-Sierra, A., Alverez, L. A., Vercauteren, A., Heungens, K. and Abad-Campos, P. 2011. Genetic diversity, sensitivity to phenylamide fungicides and aggressiveness of Phytophthora ramorum on Camellia, Rhododendron, and Viburnum plants in Spain. Plant Pathol. 60:1069-1076.

Poucke, K. V., Franceschini, S., Webber, J. F., Vercauteren, A., Tunner, J. A., Mccracken, A. R., Heungens, K. and Brasier, C. M. 2012. Discovery of a fourth evolutionary lineage of Phytophthora ramorum: EU2. Fungal Biol. 116:1178-1191.

Redlin, S. C., Werres, S. and Schroder, T. 2014. Chapter 19 Invasive pathogens in plant biosecurity. Case study: Phytophthora ramorum: cause of sudden oak death, ramorum leaf blight and ramorum dieback, In: Gordh, G. and McKirdy, S. (eds.)
The Handbook of Plant Biosecurity, Springer, pp. 593-611.

Rizzo, D. M., Garbelotto, M., Davidson, J. M. and Slaughter, G. W. 2002. Phytophthora ramorum as the cause of extensive mortality of Quercus spp. and Lithocarpus densiflorus in California. Plant Dis. 86:205-214.

Rizzo, D. M, Garbelotto, M. and Hansen, E. A. 2005. Phytophthora ramorum: Integrative research and management of an emerging pathogen in California and Oregon forests. Annu. Rev. Phytopathol. 43:309-335.

Safaiefarahani, B., Mostowfizadeh-Ghalamfarsa, R. and Cooke, D. E. 2013. Characterisation of Phytophthora inundata according to host range, morphological variation and multigene molecular phylogeny. Phytopathol. Mediterr. 52:46-65.

Sansford, C. E., Inman, A. J., Baker, R., Brasier, C., Frankel, S., de Gruyter, J., Husson, C., Kehlenbeck, H., Kessel, G., Moralejo, E., Steeghs, M., Webber, J. and Werres, S. 2009. Report on the risk of entry, establishment, spread and socioeconomic loss and environmental impact and the appropriate level of management for Phytophthora ramorum for the EU. Deliverable Report 28. Sand Hutton, York, UK: Forest Research, Central Science Laboratory. EU Sixth Framework Project, RAPRA. 310pp.

Santini, A., Biancalani, F., Barzanti, G. P. and Capretti, P. 2006. Pathogenicity of four Phytophthora species on wild cherry and Italian alder seedlings. J. Phytopathol. 154:163-167.

Schena, L., Hughes, K. J. D. and Cooke, D. E. 2006. Detection and quantification of Phytophthora ramorum, P. kernoviae, $P$. citricola and $P$. quercina in symptomatic leaves by multiplex real-time PCR. Mol. Plant Pathol. 7:365-379.

Schumann, G. L. 1991. Plant diseases: their biology and social impact. American Phytopathological Society, St. Paul, 397pp.

Siwecki, R. and Liese, W. 1991. Oak decline in Europe, In: Siwecki, R. and Liese, W. (eds.) Proceedings International Symposium, Polish Academy of Science, 7pp.

Stukely, M. J. C., Webster, J. L., Ciampini, J. A., Brown, E., Dunstan, W. A. Hardy, G. E. St. J., Woodman, G. J., Davison, E. M. and Tay, F. C. S. 2007. Phytophthora inundata from native vegetation in Western Australia. Australas. Plant Pathol. 36:606-608.

Svihra, P. 2001. Diagnosis of SOD: case study of a scientific process. Calif. Agric. 55:12-16.

The Korean Society of Plant Pathology (KSPP). 2009. List of plant diseases in Korea. 5th ed. KSPP, Suwon, Korea, 853pp. (in Korean)

Tomlinson, J. A., Dickinson, M., Hobden, E., Robinson, S., Giltrap, P. M. and Boonham, N. 2010. A five-minute DNA extraction method for expedited detection of Phytophthora ramorum following prescreening using Phytophthora spp. lateral flow devices. J. Microbiol. Methods 81:116-120.

Tooley, P. W., Browning, M. and Berner D. 2008. Recovery of Phytophthora ramorum following exposure to temperature extremes. Plant Dis. 92:431-437.

Vercauteren, A., De Dobbelaere, I., Van Bockstaele, E., Maes, M. and Heungens, K. 2011. Genotypic and phenotypic charac- 
terization of the European A2 isolates of Phytophthora ramorum. Eur. J. Plant Pathol. 129:621-635.

Vial, A., Latorre, B. A. and Ortúzar, J. 2006. Characterization of Phytophthora citrophthora and P. inundata associated to foot and root rot of citrus trees in Chile. Ciencia e Investigación Agraria 33:173-184.

Werres, S. and De Merlier, D. 2003. First detection of Phytophthora ramorum mating type A2 in Europe. Plant Dis. 87:1266.

Werres, S., Marwitz, R., Man In’T Veld, W. A., De Cock, A. W.
A. M., Bonants, P. J. M., De Weerdt, M., Themann, K., Ilieva, E. and Baayen, R. P. 2001. Phytophthora ramorum sp. nov., a new pathogen on Rhododendron and Viburnum. Mycol. Res. 105:1155-1165.

Werres, S. and Zielke, B. 2003. First studies on the pairing of Phytophthora ramorum. J. Plant Dis. Prot. 110:129-130.

Widmer, T. L. and Dodge, S. C. 2013. Can fungal epiphytes reduce disease symptoms caused by Phytophthora ramorum? Biol. Control 65:135-141. 